Copyright (C) 2016 by Academic Publishing House Researcher

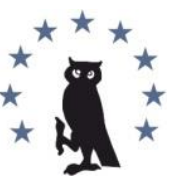

Published in the Russian Federation

European Researcher

Has been issued since 2010.

ISSN 2219-8229

E-ISSN 2224-0136

Vol. 109, Is. 8, pp. 450-455, 2016

DOI: $10.13187 /$ er.2016.109.450

www.erjournal.ru

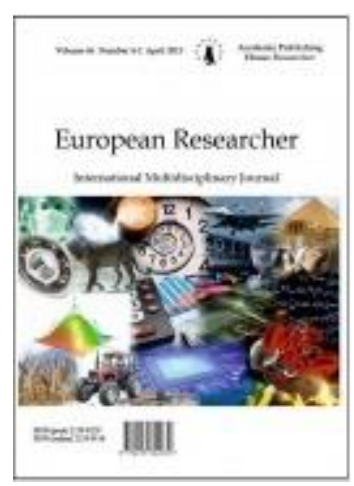

UDC 342.721

\title{
Features Consolidation and the Right to Freedom Personality in Law of Modern Russia
}

\author{
Alexander Kalyuzhnyi \\ Fellow of the Academy of Federal Security Service of Russia (Orel), \\ Academy of Federal Security Service of Russia, Russian Federation \\ 302034 Orel Priborostroitelnaya Str., 35 \\ PhD, Associate Professor \\ E-mail: kaluzniy-a-n@yandex.ru
}

\begin{abstract}
The article substantiates the urgency of countering the spread of attacks on freedom of the individual; analyzes the provisions of the Russian legislation on the declaration, and securing the rights to freedom of the individual; a classification of the investigated legal acts; substantiates the content structure of each of the listed groups of regulations; the content of the right to freedom of movement and the prohibition of forced labor in the legislation of Russia, analyzes the limits of jurisdiction of the Russian Federation and its members in matters of freedom of the individual; The problems of the existing mechanisms for the implementation of the provisions of the investigated legal acts; the features of the current state of the legal regulation of the right to individual freedom and draws conclusions on the content of the article.

Keywords: Russian legislation, regulations, individual freedom, freedom of movement, slavery, forced labor, the mechanism of implementation.

\section{Introduction}

Changes in the socio-economic life of our society, growing unemployment and a decrease in the level of social protection of the population provoke the appearance of uncontrolled criminal migration processes involving kidnapping, trafficking, use of slave labor. International crime is actively used in our society processes, formed on the territory of Russia and CIS market is intense action to involve citizens in prostitution, pornography, trafficking in human beings and their organs, their use of slave labor.

Efficiency counteract these criminal attacks depends on the legal construction standards, particularly involving the implementation and guarantee the right to freedom of the individual in modern Russian law, the analysis of which allows them to be classified into the following groups: a) the norms of international law; b) the constitution of the Russian Federation; c) sectoral legislation of Russia; g) specialized legislation.

The international legal team of documents establishing the freedom of the individual, make regulations, which were adopted by the UN, the Council of Europe, other international organizations and ratified by the Russian Federation. Fundamental documents of this group are adopted by the General Assembly of the United Nations Universal Declaration of Human Rights of
\end{abstract}


1948, the International Covenant on Civil and Political Rights of 1966, the International Covenant on Economic, Social and Cultural Rights of 1966 and the Convention for the Protection of Human Rights and Fundamental Freedoms [1: 14-40].

\section{Methods and methodology}

The methodological basis for the study is based on the dialectical method of knowledge of social and legal phenomena, the unity of their social content and legal form, providing a scientific, comprehensive, organizational, functional and activity approach to the study of international law and domestic norms establishing and guaranteeing the right to personal freedom. The study authors used legal, sociological and other methods of scientific knowledge: logical, comparative legal, system analysis and modeling features can justify the implementation of international legal standards into domestic legislation of modern Russia.

\section{Discussion}

The basis of Russian legislation are the provisions of the Constitution, proclaiming and guaranteeing universally recognized principles and norms of international law the right of everyone to freedom (article 22) [2]. And as rightly identified in its judgment the Constitutional Court of the Russian Federation, this right implies the possibility to be free from the restrictions that are associated with the use of coercive measures as detention, arrest, detention or imprisonment in all other forms without envisaged in the law, sanctions the court, as well as over the established or controlled terms [3].

Also, the Russian Constitution guarantees everyone the right to move freely and choose their place of residence, as well as the right to freely leave the country and return to it (article 27). Freedom of movement, residence and place of residence is an essential element of individual liberty, an important condition for its free development, established as the norms of international law and the Constitution of the Russian Federation. This right, like other basic human rights and freedoms, is inalienable and belong to everyone from birth [4].

One of the inalienable rights enshrined in the Constitution of the Russian Federation, and closely linked to the right to personal freedom is the freedom of labor and prohibition of forced labor (article 37). Freedom of labor should be seen as a universal constitutional and legal principles applicable to all types of work [5, p. 317]. The right to free labor, is recognized not only in Russia but also a number of international regulations, violation of which contain signs of crimes that infringe on the freedom of the individual as the use of slave labor, human trafficking, involvement in prostitution and organizing prostitution.

At the same time, the proclamation of the basic principles and norms of international law and the prohibition of their violation in the text of the Constitution of the Russian Federation does not mean their implementation. We need a clear and effective mechanism for realization of the above standards in the life of the citizens, which is based on delineation of authority between the Russian Federation and its subjects. So in $\mathrm{n}$. «b» article 71 of the Russian Constitution stipulates that the exclusive jurisdiction of the Russian Federation is the regulation and protection of the rights and freedoms of man and citizen, at the same time $n$. «b» of article 72 of the Russian Constitution states that the joint jurisdiction of the Russian Federation and its subjects is to protect the rights and freedoms of man and citizen.

Thus, regulation of the rights and freedoms of man and citizen, referred to the exclusive jurisdiction of the Russian Federation, is a public and legal recognition of individual liberty, the establishment of its normative content, conditions and opportunities for the implementation of limitations. The joint jurisdiction of the Russian Federation and its subjects of the Russian Constitution assigns responsibility as public bodies and local authorities to ensure the implementation of the freedom of the individual, to eliminate obstacles as well as protection from possible violations.

Thus, the state determines the most effective measures to monitor the implementation of the constitutional provisions to ensure the freedom of the individual, developing activities in this area, provides a way of combating illicit restriction and deprivation of personal freedom.

At the same time, the Constitution establishes only the basic directions of activity of the state in the sphere of individual freedom, the provisions of which find their concretization in the norms of sectoral legislation in the sphere of individual freedom and countering its unlawful restriction or 
deprivation. Power industry of legal acts in the context of certain earlier concepts of individual liberty, make documents governing freedom of movement. Among them, the Russian Federation Law «On the right of citizens of the Russian Federation to freedom of movement and choice of place of residence within the Russian Federation».

Analyzed the law provides that every citizen of the Russian Federation, as well as persons who are not citizens of the Russian Federation legally residing in its territory, have the right to freedom of movement and choice of place of residence within the Russian Federation (article 1), prohibiting their illegal restriction or deprivation. In order to implement the rights and freedoms of Russian citizens considered the law introduces the register at the place of residence and place of residence (article 3), but is fixed, that the presence or absence of registration cannot serve as the basis for the restriction or condition for the realization of this right, as well as the grounds for regulated restrictions on the right to freedom of movement and choice of place of residence (article 8) [6].

One of the basic industry of legal acts in our coverage area is the Federal Law «On the Procedure for Exit from the Russian Federation and Entry to the Russian Federation», the preamble of which establishes the right of everyone to freely leave the Russian Federation and the right of Russian citizens to freely return to the country. Viewed Federal Law establishes the procedure for entry and departure from the country of citizens of the Russian Federation, foreign citizens and stateless persons, prohibiting the restriction of these rights (article 2). In addition, the analyzed regulation contains a list of grounds, allowing to limit the right of Russian citizens to leave the country (article 15), and a list of reasons that do not allow the possibility of entry of foreign citizens or stateless persons (article 27) [7].

Analyzed normative acts embody the legal consolidation of international standards and the Constitution of the Russian Federation to freedom of movement and choice of place of residence, freedom of entry and exit in the country for the mechanisms for the implementation of these rights, and also contain the legal and not subject to an expanded interpretation of the list of reasons for their limitation.

International prohibition of slavery and legal basis of state guarantees of free labor, who found embodied in the Constitution of the Russian Federation, are detailed in the Labour Code. Freedom to work and the prohibition of forced its forms enshrined as fundamental principles of labor law (article 2). The Labour Code defines forced labor and transfers it to the form (article 4), regulates the basic rights and duties of the employee (article 21) and the employer (article 22), introduces the concept of working time and determines its duration (article 91), establishes labor guarantees of workers, defines responsibilities of the parties [8].

Thus, power industry regulatory acts detail the principle of individual freedom enshrined in international regulations, that complements the conceptual framework in this area, regulates the procedures for the implementation of individual liberty, it contains guarantees for its implementation and establishes a clear list of grounds for limiting freedom considered.

At the same time, combating illegal restriction or deprivation of personal freedom, except for international legal norms, the Constitution of the Russian Federation and the sectoral legislation is reflected in the regulations of normative legal acts, which are specialized legislation narrowly focused areas of its implementation, a limited period, the territory of the action, and so on.

For example, in order to implement the UN Convention against Transnational organized crime was adopted by Presidential Decree №1362 «On the central authorities of the Russian Federation responsible for the implementation of the provisions of the United Nations Convention against Transnational Organized Crime, relating to mutual legal assistance» [9]. Considered by the Decree on the ministry of justice and the General prosecutor's office are obliged to provide legal assistance in civil and criminal cases, respectively, in the fight against transnational organized crime.

Presidential Decree №977 of June 17, 2008 «On the order of entry into the Russian Federation and exit from the Russian Federation, stateless persons, citizens of the USSR, and living in the Republic of Latvia and the Republic of Estonia», governed by specific issues of entry and exit from the Russian Federation certain categories of persons [10].

Government Decree №1142 dated October 1, 1998 «On the implementation of certain provisions of the federal law» on the Procedure for Exit from the Russian Federation and Entry to the Russian Federation approved by the Regulation on the registration in the Ministry of foreign affairs of the Russian Federation, Regulations on the registration certificate to enter the Russian 
Federation, Regulation on the registration of the invitation to the Russian Federation of foreign citizens and stateless persons and others [11].

It is clear that special legal acts are governed by specific forms of implementation of the principle of individual freedom and specifies the order of the restriction or deprivation of liberty. At the same time, there are many other legal documents relating to the ad hoc group, which regulate the sphere of realization of narrowly focused and combating illegal restriction of personal freedom $[12,13,14]$, the analysis of which, in our opinion, is inappropriate.

\section{Results}

1. Personal freedom is a fundamental, inalienable right of every person, the value of which is recognized and guaranteed the title documents of the international community.

2. After analyzing the foundations of securing the right to personal liberty in the legislation of modern Russia, we note that regulations in this area, with adjacent areas of regulation, can be roughly classified into the following groups: international regulations, the Constitution of the Russian Federation, branch and specialized legislation Russia.

3. Constitutional and legal provisions concerning the freedom of the individual, is the fundamental core of not only the establishment and proclamation of the right to personal freedom, but also the guarantor of the mechanism of realization of this right.

4. The effectiveness of the operation and implementation of the right to freedom of the individual depends on the legal and regulatory framework, based on a set of different levels of legal norms regulating legal relations related and associated with both the establishment of the test of law and responsibilities for securing compliance.

\section{Conclusion}

After securing the fundamental rights and freedoms of man and citizen, the international community has allocated among them, and the right to personal freedom, the value of which is indisputable. Acting as a State party of various international organizations, Russia has ratified a set of inter-state regulations, committing to bring its domestic legislation into conformity with the requirements of international law. Warranty of the right to freedom of the individual in the Russian Federation is provided by a set of internal regulations, reflecting the basic provisions of international law.

\section{Литература}

1. Международная защита прав и свобод человека. Сборник документов. М.: Юридическая литература, 1990. С. 14-40.

2. Конституция РФ // СЗ РФ. 26.01.2009. №4. ст. 445.

3. Постановление Конституционного Суда РФ от 13.06.1996 №14-П «По делу о проверке конституционности части пятой статьи 97 Уголовно - процессуального кодекса РСФСР в связи с жалобой гражданина В.В. Щелухина» // СЗ РФ. 24.06.1996. №26. ст.3185.

4. Постановление Конституционного Суда РФ от 4 апреля 1996 г. №9-п «По делу о проверке конституционности ряда нормативных актов города Москвы и Московской области, Ставропольского края, Воронежской области и города Воронежа, регламентирующих порядок регистрации граждан, прибывающих на постоянное жительство в названные регионы» // СПС «ГАРАНТ».

5. Комментарий к Конституции Российской Федерации / под ред. В.Д. Зорькина, Л.В. Лазарева. М.: Эксмо. 2010. С. 317.

6. Закон Российской Федерации «О праве граждан Российской Федерации на свободу передвижения, выбор места пребывания и жительства в пределах Российской Федерации» // Российская газета. №152. 10.08.1993.

7. Федеральный Закон Российской Федерации «О порядке выезда из Российской Федерации и въезда в Российскую Федерацию» // СЗ РФ. 19.08.1996. №34. ст. 4029.

8. Трудовой Кодекс РФ // СЗ РФ. 07.01.2002. №1. ч.1. ст. 3.

9. Указ Президента РФ №1362 «О центральных органах Российской Федерации, ответственных за реализацию положений Конвенции Организации Объединенных Наций против транснациональной организованной преступности, касающейся взаимной правовой помощи» // С3 РФ. 01.11.2004. №44. ст. 4327. 
10. Указ Президента РФ №977 от 17 июня 2008 г. «О порядке въезда в Российскую Федерацию и выезда из Российской Федерации лиц без гражданства, состоявших в гражданстве СССР и проживающих в Латвийской Республике или Эстонской Республике» // СЗ РФ. 23.06.2008. №25. ст. 2959.

11. Постановление Правительства РФ №1142 от 1 октября 1998 г. «О реализации отдельных норм федерального закона «О порядке выезда из российской федерации и въезда в Российскую Федерацию» // С3 РФ. 12.10.1998. №41. ст. 5020.

12. Указ Президента РФ №773 от 13.05.2008 г. «О порядке въезда в Российскую Федерацию и выезда из Российской Федерации иностранных граждан и лиц без гражданства в связи с проведением в г.Москве в 2008 г. финального футбольного матча лиги чемпионов УЕФА» // СЗ РФ. 19.05.2008. №20. ст. 2291.

13. Определение Конституционного Суда РФ от 16.07.2009 № 935-О-О «Об отказе в принятии к рассмотрению жалобы гражданина Круглова Тимофея Владиславовича на нарушение его конституционных прав статьей 9 Федерального закона «О порядке выезда из Российской Федерации и въезда в Российскую Федерацию» // Вестник КС РФ. №6. 2009.

14. Распоряжение губернатора Санкт-Петербурга от 24.02.1998 №185-p «О мерах по реализации в Санкт-Петербурге Федерального закона «О порядке выезда из Российской Федерации и въезда в Российскую Федерацию» // Вестник Администрации СанктПетербурга. №4. 1998.

\section{References}

1. Mezhdunarodnaya zashchita prav i svobod cheloveka. Sbornik dokumentov. M.: Yuridicheskaya literatura, 1990.

2. Konstitutsiya Rossiiskoi Federatsii // Sobranie Zakonodatel'stva Rossijskoj Federacii. 26.01.2009. №4. st. 445 .

3. Postanovlenie Konstitutsionnogo Suda Rossiiskoi Federatsii ot 13.06.1996 №14-P «Po delu o proverke konstitutsionnosti chasti pyatoi stat'i 97 Ugolovno - protsessual'nogo kodeksa RSFSR v svyazi s zhaloboi grazhdanina V.V. Shchelukhina»// Sobranie Zakonodatel'stva Rossijskoj Federacii. 24.06.1996. №26. st. 3185.

4. Postanovlenie Konstitutsionnogo Suda Rossiiskoi Federatsii ot 4 aprelya 1996 g. №9-p «Po delu o proverke konstitutsionnosti ryada normativnykh aktov goroda Moskvy i Moskovskoi oblasti, Stavropol'skogo kraya, Voronezhskoi oblasti i goroda Voronezha, reglamentiruyushchikh poryadok registratsii grazhdan, pribyvayushchikh na postoyannoe zhitel'stvo v nazvannye regiony» // SPS «GARANT».

5. Kommentarii k Konstitutsii Rossiiskoi Federatsii / pod red. V.D. Zor'kina, L.V. Lazareva. M.: Eksmo. 2010. S. 317.

6. Zakon Rossiiskoi Federatsii «O prave grazhdan Rossiiskoi Federatsii na svobodu peredvizheniya, vybor mesta prebyvaniya i zhitel'stva v predelakh Rossiiskoi Federatsii» // Rossiiskaya gazeta. №152. 10.08.1993.

7. Federal'nyi Zakon Rossiiskoi Federatsii «O poryadke vyezda iz Rossiiskoi Federatsii i v"ezda v Rossiiskuyu Federatsiyu» // Sobranie Zakonodatel'stva Rossijskoj Federacii. 19.08.1996. №34. st. 4029.

8. Trudovoi Kodeks Rossiiskoi Federatsii // Sobranie Zakonodatel'stva Rossijskoj Federacii. 07.01.2002. №1. ch.1. st. 3 .

9. Ukaz Prezidenta Rossiiskoi Federatsii №1362 «O tsentral'nykh organakh Rossiiskoi Federatsii, otvetstvennykh za realizatsiyu polozhenii Konventsii Organizatsii Ob"edinennykh Natsii protiv transnatsional'noi organizovannoi prestupnosti, kasayushcheisya vzaimnoi pravovoi pomoshchi» // Sobranie Zakonodatel'stva Rossijskoj Federacii. 01.11.2004. №44. st. 4327.

10. Ukaz Prezidenta Rossiiskoi Federatsii №977 ot 17 iyunya 2008 g. «O poryadke v"ezda v Rossiiskuyu Federatsiyu i vyezda iz Rossiiskoi Federatsii lits bez grazhdanstva, sostoyavshikh v grazhdanstve SSSR i prozhivayushchikh v Latviiskoi Respublike ili Estonskoi Respublike»// Sobranie Zakonodatel'stva Rossijskoj Federacii. 23.06.2008. №25. st. 2959.

11. Postanovlenie Pravitel'stva Rossiiskoi Federatsii №1142 ot 1 oktyabrya $1998 \mathrm{~g}$. «O realizatsii otdel'nykh norm federal'nogo zakona «O poryadke vyezda iz rossiiskoi federatsii i v"ezda v Rossiiskuyu Federatsiyu» // Sobranie Zakonodatel'stva Rossijskoj Federacii. 12.10.1998. №41. st.5020. 
12. Ukaz Prezidenta Rossiiskoi Federatsii №773 ot 13.05.2008 g. "O poryadke v"ezda v Rossiiskuyu Federatsiyu i vyezda iz Rossiiskoi Federatsii inostrannykh grazhdan i lits bez grazhdanstva v svyazi s provedeniem v g. Moskve v $2008 \mathrm{~g}$. final'nogo futbol'nogo matcha ligi chempionov UEFA» // Sobranie Zakonodatel'stva Rossijskoj Federacii. 19.05.2008. №20. st.2291.

13. Opredelenie Konstitutsionnogo Suda Rossiiskoi Federatsii ot 16.07.2009. №935-O-O «Ob otkaze v prinyatii k rassmotreniyu zhaloby grazhdanina Kruglova Timofeya Vladislavovicha na narushenie ego konstitutsionnykh prav stat'ei 9 Federal'nogo zakona «O poryadke vyezda iz Rossiiskoi Federatsii i v"ezda v Rossiiskuyu Federatsiyu» // Vestnik KS RF. №6. 2009.

14. Rasporyazhenie gubernatora Sankt-Peterburga ot 24.02.1998 №185-r «O merakh po realizatsii v Sankt-Peterburge Federal'nogo zakona «O poryadke vyezda iz Rossiiskoi Federatsii i v"ezda v Rossiiskuyu Federatsiyu» // Vestnik Administratsii Sankt-Peterburga. №4. 1998.

УДК 342.721

\section{Особенности закрепления и реализации права на свободу личности в законодательстве современной России}

Александр Николаевич Калюжный

Академия ФСО России, Российская Федерация

302034 г. Орел ул. Приборостроительная д. 35

Кандидат юридических наук, доцент

E-mail: kaluzniy-a-n@yandex.ru

Аннотация. В статье обосновывается актуальность противодействия распространению посягательств на свободу личности; анализируются положения российского законодательства в сфере провозглашения и закрепления права на свободу личности; проводится классификация исследуемых правовых актов; обосновывается содержание структуры каждой из классифицированных групп нормативных правовых актов; раскрывается содержание права на свободу передвижения и запрет принудительного труда в законодательстве России, анализируются пределы ведения Российской Федерации и ее субъектов в вопросах обеспечения права на свободу личности; исследуются проблемы действующих механизмов реализации положений исследуемых правовых актов; рассматриваются особенности современного состояния правового регулирования права на свободу личности, и делаются выводы по содержанию статьи.

Ключевые слова: законодательство России, нормативные правовые акты, свобода личности, свобода передвижения, рабство, принудительный труд, механизм реализации. 